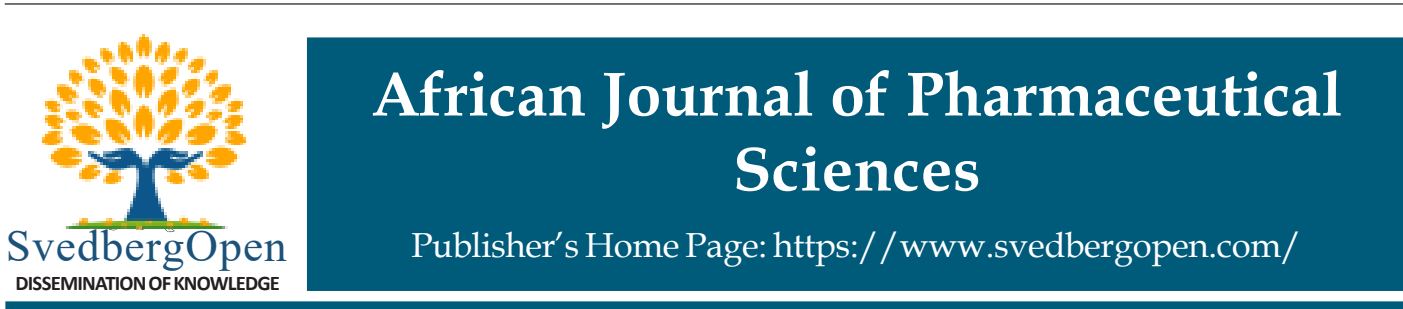

Research Paper

Open Access

\title{
Mixed Ligand Oxovanadium (IV) Complexes of 5,6-Dimethyl-1,10- phenanthroline and Amino Acid Schiff Bases Containing Salicylaldehyde: Synthesis and Characterization with Antibacterial Properties
}

\author{
Md. Nur Amin Bitu ${ }^{1}$, Md. Saddam Hossain ${ }^{2}$, Md. Ali Asraf ${ }^{3}$, Md. Faruk Hossen ${ }^{4}$ and Md. Kudrat-E-Zahan ${ }^{5 *}$ \\ ${ }^{1}$ Department of Chemistry, University of Rajshahi, Rajshahi-6205, Bangladesh. E-mail: nabitu.ru@gmail.com \\ ${ }^{2}$ Department of Chemistry, Begum Rokeya University, Rangpur-5400, Bangladesh. E-mail: saddamru4535@gmail.com \\ ${ }^{3}$ Department of Chemistry, University of Rajshahi, Rajshahi-6205, Bangladesh. E-mail: asraf.chem@ru.ac.bd \\ ${ }^{4}$ Department of Chemistry, University of Rajshahi, Rajshahi-6205, Bangladesh. E-mail: fhossen.chem@ru.ac.bd \\ ${ }^{5}$ Department of Chemistry, University of Rajshahi, Rajshahi-6205, Bangladesh. E-mail: kudrat.chem@ru.ac.bd
}

\section{Article Info}

Volume 1, Issue 1, September 2021

Received : 29 November 2020

Accepted : 12 June 2021

Published : 05 September 2021

doi: 10.51483/AFJPS.1.1.2021.47-53

\begin{abstract}
Five new oxovanadium (IV) complexes have been synthesized from two mixed ligand, 5,6-Dimethyl-1,10-phenanthroline and amino acid derived Schiff bases containing salicylaldehyde. All the synthesized complexes were characterized by some physicochemical properties, molar conductance, magnetic susceptibilities measurements, elemental analysis, UV-Visible and IR spectral studies. The molar conductance values reveal the non-electrolytic nature of the complexes. The magnetic moment values indicate that the complexes are paramagnetic in nature. IR spectral data indicates the coordination of tridentate amino acid Schiff base ligands to the vanadyl $\left(\mathrm{VO}^{2+}\right)$ ion through $\mathrm{O}, \mathrm{N}, \mathrm{O}-$ donor. ESI-MS spectral data confirms the proposed molecular formula of the complexes. All the analytical data suggested that all the complexes possess to have distorted octahedral geometry. Antibacterial activity of the complexes was tested against two Gram positive bacteria Escherichia coli and Pseudomonas aeruginosa and two Gram negative bacteria Staphylococcus aureus and Bacillus cereus with Kanamycin (K-30) standard. The result shows that all the complexes possess to have moderate to strong potential antibacterial activity against all the tested pathogenic bacteria.
\end{abstract}

Keywords: Oxovanadium (IV) complexes, 5,6-Dimethyl-1,10-phenanthroline, Amino acids, Salicylaldehyde, Schiff base, Antibacterial activity

C 2021 Md. Nur Amin Bitu et al. This is an open access article under the CC BY license (https://creativecommons.org/licenses/by/4.0/), which permits unrestricted use, distribution, and reproduction in any medium, provided you give appropriate credit to the original author(s) and the source, provide a link to the Creative Commons license, and indicate if changes were made.

\section{Introduction}

Schiff bases are the condensation products of primary amines and carbonyl compounds. They contain imine or azomethine $(-\mathrm{RC}=\mathrm{N}-)$ group in their structural formula (Bitu et al., 2019). Amino acids are the significant class of organic-based compounds which may take part to prepare Schiff base by condensation of amine group $\left(\mathrm{NH}_{2}\right)$ with any carbonyl

\footnotetext{
* Corresponding author: Md. Kudrat-E-Zahan, Department of Chemistry, University of Rajshahi, Rajshahi-6205, Bangladesh. E-mail: kudrat.chem@ru.ac.bd
} 
compound. They contain potential donor sites such as $\mathrm{COOH}$ and/or $\mathrm{NH}_{2}$ group which have good ability to coordinate with the central metal ions. As an excellent complexing agent Schiff bases can form various complexes with several transition and inner transition metals. Schiff base ligands and their transition metal complexes have a variety of applications including biological, clinical, and analytical applications (Cheng et al., 2010; Ran et al., 2011; and KudratE-Zahan et al., 2019). Vanadium coordination chemistry is a topic of interest over the last few decades due to the role of vanadium in various biological processes, such as phosphorylation (Yue et al., 2006), haloperoxidation (MacedoRibeiro et al., 1999) enhancement of oxygen affinity of hemoglobin and myoglobin (Noblía et al., 2004; and Pattanayak et al., 2009) insulin mimicking, etc. (Tasiopoulos et al., 1999; and Thompson et al., 1999). Several studies on the synthesis of vanadium complexes of $\mathrm{N}$-salicylidene amino acids have been reported, most of which were synthesized from amino acids and salicylaldehyde (Pessoa et al., 2002; and 2004).

On continuation of the above studies, in our current research five new oxovanadium (IV) complexes containing two mixed ligand, 5,6-Dimethyl-1,10-phenanthroline and Schiff bases derived from amino acids and salicylaldehyde were prepared, characterized and investigated their potential antibacterial activity.

\section{Materials and Methods}

\subsection{Reagents and Chemicals}

All the reagents used were of chemically pure grade. Solvents were purified and dried according to standard procedures.

\subsection{Physical Measurements}

All the weighing operations was carried out by using A Mettler PM-200 electronic balance. The melting point of all the synthesized metal complexes were recorded in an electro thermal melting point apparatus (model No. AZ6512). Conductivities of $1.0 \times 10^{-3} \mathrm{~mol} / \mathrm{dm}^{3}$ solutions of the complexes in DMF were measured at $30{ }^{\circ} \mathrm{C}$ using a WPA CM 35 conductivity meter and a dip-cell with platinized electrodes. The magnetic moment value was measured by a SHERWOOD SCIENTIFIC Magnetic Susceptibility Balance. Infrared spectra were recorded as KBr disc in a SIMADZU FTIR-8400 (Japan) infrared spectrophotometer, at the Central Science Laboratory of Rajshahi University, from 4000-225 $\mathrm{cm}^{-1}$. The electronic spectra of the complexes were recorded on SHIMUDZU Spectrophotometer (Model UV-1800). The ESI-MS spectra were performed using a Shimadzu Ge Ms Qp 100 EX mass spectrometer using the direct inlet system. Carbon, hydrogen and nitrogen analyses for the complexes were carried out by PerkinElmer 2400 organic elemental analyzer-II.

\subsection{General Method for the Preparation of the Oxovanadium (IV) Complexes of Type [VO(L) (DPhen)]}

Oxovanadium (IV) complexes were prepared by template method in which a mixture of $\alpha$-amino acids, $\alpha$-alanine (ala) (0.267 g, $3 \mathrm{mmol}$ )/DL-phenylalanine (pheala) (0.495 g, $3 \mathrm{mmol}) /$ leucine (leu) ( $0.393 \mathrm{~g}, 3 \mathrm{mmol}$ )/glycine (gly) (0.225 g, $3 \mathrm{mmol}) / \mathrm{DL}-m e t h i o n i n e ~(\mathrm{met})(0.447 \mathrm{~g}, 3 \mathrm{mmol})$ and $\mathrm{NaOH}(0.12 \mathrm{~g}, 3 \mathrm{mmol})$ in $10 \mathrm{~mL}$ methanol were added to a methanolic solution of salicylaldehyde ( $\mathrm{sal})(0.31 \mathrm{~mL}, 3 \mathrm{mmol})$ in a round bottom flask. The resulting solution was refluxed for 1 hour, followed by the addition of a methanolic solution of vanadyl sulfate $(0.489 \mathrm{~g}, 3 \mathrm{mmol})$. A light precipitate was obtained after refluxing the mixture for $1 \mathrm{~h}$. To this mixture, 5,6-Dimethyl-1,10-phenanthroline (DPhen) (0.625 g, $3 \mathrm{mmol})$ taken in $10 \mathrm{~mL}$ methanol was added. The solution on further refluxing for $1 \mathrm{~h}$ gave a precipitate. The precipitate was filtered off on a Buchner funnel, washed with methanol and finally dried in a vacuum desiccator over anhydrous $\mathrm{CaCl}_{2}$ (Sasmal et al., 2007).

The general synthetic method is shown below:

$\mathrm{VOSO}_{4}+\mathrm{L}+\mathrm{DPhen} \rightarrow[\mathrm{VO}(\mathrm{L})(\mathrm{DPhen})]$

where, $\mathrm{L}=\mathrm{N}$-salicylidene- $\alpha$-alanine (sal-ala), N-salicylidene-DL-phenylalanine (sal-pheala), N-salicylidene-leucine (salleu), N-salicylidene-glycine (sal-gly), N-salicylidene-DL-methionine (sal-met) and DPhen=5,6-Dimethyl-1,10phenanthroline.

\subsubsection{Oxovanadium(IV) complex of a-alanine [VO(sal-ala)(DPhen)]}

Color: Brown, Melting point: $217^{\circ} \mathrm{C}$, Yield: $0.825 \mathrm{~g}(59 \%)$, Molar conductance $\left(\mathrm{Ohm}^{-1} \mathrm{~cm}^{2} \mathrm{~mol}^{-1}\right)$ : 15.1, Magnetic moment $\left(\mu_{\text {eff }} /\right.$ B.M. $): 1.65$, FT-IR $\left(\mathrm{cm}^{-1}\right): 3454 \mathrm{br}, v(\mathrm{OH}) ; 1620 \mathrm{vs}, v(\mathrm{C}=\mathrm{O}) ; 1537 \mathrm{~m}, v(\mathrm{C}=\mathrm{N}) ; 1312 \mathrm{~m}, \mathrm{v}(\mathrm{C}-\mathrm{O}) ; 959 \mathrm{~s}, \mathrm{v}(\mathrm{V}=\mathrm{O}) ; 613 \mathrm{~m}$, $v(\mathrm{~V}-\mathrm{O}) ; 456 \mathrm{~m}, v(\mathrm{~V}-\mathrm{N}), \mathrm{UV}-\mathrm{Vis} .\left(\lambda_{\max } / \mathrm{nm}\right): 268-302,363,378$. Elemental analysis for $\left[\mathrm{VOC}_{24} \mathrm{H}_{21} \mathrm{~N}_{3} \mathrm{O}_{3}\right]$ : M.W. $466.38 \mathrm{~g} / \mathrm{mol}$ : Calculated: C, 61.81; H, 4.54; N, 9.01\%. Found: C, 61.07; H, 4.35; N, 9.11\%. 


\subsubsection{Oxovanadium (IV) Complex of DL-phenylalanine [VO(sal-pheala)(DPhen)]}

Color: Orange, Melting point: $210^{\circ} \mathrm{C}$, Yield: $0.928 \mathrm{~g}(57 \%)$, Molar conductance $\left(\mathrm{Ohm}^{-1} \mathrm{~cm}^{2} \mathrm{~mol}^{-1}\right): 18.2$, Magnetic moment $\left(\mu_{\text {eff }} /\right.$ B.M. $): 1.58$, FT-IR $\left(\mathrm{cm}^{-1}\right): 3435 \mathrm{br}, v(\mathrm{OH}) ; 1621 \mathrm{vs}, v(\mathrm{C}=\mathrm{O}) ; 1542 \mathrm{~s}, v(\mathrm{C}=\mathrm{N}) ; 1310 \mathrm{~m}, \mathrm{v}(\mathrm{C}-\mathrm{O}) ; 941 \mathrm{~s}, v(\mathrm{~V}=\mathrm{O}) ; 612 \mathrm{~m}, v(\mathrm{~V}-$ O); $446 \mathrm{~m}, v(\mathrm{~V}-\mathrm{N})$, UV-Vis. $\left(\lambda_{\max } / \mathrm{nm}\right): 269-302,363$, 375. Elemental analysis for $\left[\mathrm{VOC}_{30} \mathrm{H}_{25} \mathrm{~N}_{3} \mathrm{O}_{3}\right]$ : M.W. $542.48 \mathrm{~g} / \mathrm{mol}$ : Calculated: C, 66.42; H, 4.65; N, 7.75\%. Found: C, 65.19; H, 4.47; N, 7.58\%.

\subsubsection{Oxovanadium (IV) Complex of Leucine [VO(sal-leu)(DPhen)]}

Color: Brown, Melting point: $225^{\circ} \mathrm{C}$, Yield: $0.901 \mathrm{~g}(59 \%)$, Molar conductance $\left(\mathrm{Ohm}^{-1} \mathrm{~cm}^{2} \mathrm{~mol}^{-1}\right): 10.3$, Magnetic moment $\left(\mu_{\text {eff }}\right.$ B.M.): 1.57, FT-IR $\left(\mathrm{cm}^{-1}\right): 3453 \mathrm{w},(\mathrm{OH}) ; 1624 \mathrm{w}, v(\mathrm{C}=\mathrm{O}) ; 1533 \mathrm{w}, v(\mathrm{C}=\mathrm{N}) ; 1313 \mathrm{w}, v(\mathrm{C}-\mathrm{O}) ; 960 \mathrm{~s}, v(\mathrm{~V}=\mathrm{O}) ; 617 \mathrm{~m},(\mathrm{~V}-\mathrm{O})$; $460 \mathrm{w}, v(\mathrm{~V}-\mathrm{N}), \mathrm{UV}-\mathrm{Vis} .\left(\lambda_{\max } / \mathrm{nm}\right): 267-303,364,373$. Elemental analysis for $\left[\mathrm{VOC}_{27} \mathrm{H}_{27} \mathrm{~N}_{3} \mathrm{O}_{3}\right]$ : M.W. $508.46 \mathrm{~g} / \mathrm{mol}$ : Calculated: C, $63.78 ; \mathrm{H}, 5.35 ; \mathrm{N}, 8.26 \%$. Found: $\mathrm{C}, 63.15 ; \mathrm{H}, 4.92 ; \mathrm{N}, 8.15 \%$.

\subsubsection{Oxovanadium (IV) Complex of Glycine [VO(sal-gly)(DPhen)]}

Color: Reddish, Melting point: $213^{\circ} \mathrm{C}$, Yield: $0.855 \mathrm{~g}(63 \%)$, Molar conductance $\left(\mathrm{Ohm}^{-1} \mathrm{~cm}^{2} \mathrm{~mol}^{-1}\right): 16.5$, Magnetic moment $\left(\mu_{\text {eff }} /\right.$ B.M. $): 1.60$, FT-IR $\left(\mathrm{cm}^{-1}\right): 3429 \mathrm{br}, v(\mathrm{OH}) ; 1647 \mathrm{~s}, v(\mathrm{C}=\mathrm{O}) ; 1538 \mathrm{~s}, \mathrm{v}(\mathrm{C}=\mathrm{N}) ; 1315 \mathrm{~m}, v(\mathrm{C}-\mathrm{O}) ; 962 \mathrm{~s}, v(\mathrm{~V}=\mathrm{O}) ; 615 \mathrm{~s}$, $v(\mathrm{~V}-\mathrm{O}) ; 461 \mathrm{~m}, v(\mathrm{~V}-\mathrm{N}), \mathrm{UV}-\mathrm{Vis} .\left(\lambda_{\max } / \mathrm{nm}\right): 271-302,363,374$. Elemental analysis for $\left[\mathrm{VOC}_{23} \mathrm{H}_{19} \mathrm{~N}_{3} \mathrm{O}_{3}\right]$ : M.W. $452.36 \mathrm{~g} / \mathrm{mol}$ : Calculated: C, $61.07 ; \mathrm{H}, 4.23 ; \mathrm{N}, 9.29 \%$. Found: $\mathrm{C}, 60.56 ; \mathrm{H}, 4.11 ; \mathrm{N}, 9.13 \%$.

\subsubsection{Oxovanadium (IV) Complex of DL-methionine [VO(sal-met)(DPhen)]}

Color: Brown, Melting point: $216^{\circ} \mathrm{C}$, Yield: $0.947 \mathrm{~g}(60 \%)$, Molar conductance $\left(\mathrm{Ohm}^{-1} \mathrm{~cm}^{2} \mathrm{~mol}^{1}\right): 10.1$, Magnetic moment $\left(\mu_{\text {eff }} /\right.$ B.M. $): 1.75$, FT-IR $\left(\mathrm{cm}^{-1}\right): 3425 \mathrm{br}, v(\mathrm{OH}) ; 1639 \mathrm{~s}, v(\mathrm{C}=\mathrm{O}) ; 1536 \mathrm{~s}, v(\mathrm{C}=\mathrm{N}) ; 1311 \mathrm{~m}, v(\mathrm{C}-\mathrm{O}) ; 958 \mathrm{vs}, v(\mathrm{~V}=\mathrm{O}) ; 613 \mathrm{~m}, v(\mathrm{~V}-$ O); 453m, $v(V-N)$, UV-Vis. $\left(\lambda_{\max } / \mathrm{nm}\right)$ : 269-305, 364, 385. Elemental analysis for $\left[\mathrm{VOC}_{26} \mathrm{H}_{25} \mathrm{~N}_{3} \mathrm{O}_{3} \mathrm{~S}\right]$ : M.W. $526.50 \mathrm{~g} / \mathrm{mol}$ : Calculated: C, 59.31; H, 4.79; N, 7.98\%. Found: C, 59.14; H, 4.59; N, 7.78\%.

Here, the related band intensities for FT-IR are denoted by $v s, s, m, w$ and $b r$ representing very strong, strong, medium, weak and broad band respectively.

\section{Results and Discussion}

\subsection{Solubility and Melting Point Measurement}

All the complexes are soluble in dimethylformamide (DMF) and dimethylsulfoxide (DMSO) but insoluble in common organic solvents such as methanol, ethanol, chloroform, Carbon tetrachloride, benzene etc. Melting point $\left(210-225^{\circ} \mathrm{C}\right)$ gives an approximate idea about the nature of the complexes and can suggest whether it is covalent or ionic (Arun et al., 2009).

\subsection{Elemental Analysis and Conductivity Measurement}

The molar conductance of the complexes was measured in DMF $\left(10^{-3} \mathrm{M}\right.$ solution) at $30^{\circ} \mathrm{C}$. The molar conductance values $\left(10.1\right.$ to $\left.18.2 \mathrm{~W}^{-1} \mathrm{~cm}^{2} \mathrm{~mol}^{-1}\right)$ are lower than that expected for an electrolyte and indicate that all the complexes are non-electrolytic in nature. Based on the elemental analysis, conductivity and magnetic susceptibility measurements, IR spectral and UV-Visible spectral analysis, the structure of the complexes has been proposed (Al-Resayes et al., 2012). Also, the analytical data are in good agreement with their proposed empirical formula.

\subsection{Magnetic Moment and Electronic Spectra}

The magnetic susceptibility of the complexes was measured by a Sherwood Scientific magnetic susceptibility balance at room temperature $\left(30^{\circ} \mathrm{C}\right)$ (Kriza et al., 2005). The observed values of effective magnetic moment $\left(\mu_{\text {eff }}\right)(1.57$ to 1.75 $\mathrm{BM})$ at room temperature indicated that all the complexes are paramagnetic in nature. The electronic spectra of the complexes were recorded in DMSO in the wavelength of 200-800 $\mathrm{nm}$ range. All the complexes exhibit a shoulder in the range 373-385 nm due to ligand-to-metal charge-transfer $\left(\mathrm{LMCT}, \mathrm{PhO}^{-} \rightarrow \mathrm{V}\right)$ transition, and the remaining bands appearing in the UV region are assignable to the intraligand transitions (Dutta et al., 1997). All the complexes exhibit bands in between 267-305 $\mathrm{nm}$ which are assignable to the $\pi \rightarrow \pi^{*}$ transition (Sasmal et al., 2007).

\subsection{IR Spectral Studies}

The IR spectral data of oxovanadium (IV) complexes show a broad band in the $3425-3454 \mathrm{~cm}^{-1}$ region which is possibly 
due to the hydrated water molecule in the complexes (Maurya et al., 2001). The complexes exhibit $v(C=O)$ bands at 1620$1647 \mathrm{~cm}^{-1}$ and $v(\mathrm{C}-\mathrm{O})$ bands at $1310-1315 \mathrm{~cm}^{-1}$ which are significantly lower than the values for respective bands of uncoordinated amino acids. Again, the appearance of $v(\mathrm{~V}-\mathrm{O})$ modes in the range $612-617 \mathrm{~cm}^{-1}$ confirms the coordination of carboxylate ion to the central metal ion (Dutta and Lal, 1988). The $v(\mathrm{O}-\mathrm{H})$ band usually appeared at $\sim 3600 \mathrm{~cm}^{-1}$ for the phenolic $-\mathrm{OH}$ is absent in the present complexes which supports the coordination of phenolic oxygen to vanadyl ion. The bands appeared in the range 1533-1542 $\mathrm{cm}^{-1}$ may be assigned to $v(\mathrm{C}=\mathrm{N})$ stretching frequency suggesting the coordination of the azomethine nitrogen and heterocyclic nitrogen to the $\mathrm{VO}^{2+}$ moiety. The coordination of nitrogen of azomethine group and heterocyclic nitrogen is further evident by the appearance of $v(\mathrm{~V}-\mathrm{N})$ modes in the $446-461 \mathrm{~cm}^{-1}$ region (Singh et al., 1989). The present oxovanadium (IV) complexes exhibit the $v(\mathrm{~V}=\mathrm{O})$ stretching frequency in the 941-962 $\mathrm{cm}^{-1}$ region characteristic of metal-oxygen multiple bond (Rao et al., 1988).

\subsection{ESI-Mass Spectra}

The ESI-Mass spectra of the complexes are presented in Figure 1. The obtained $\mathrm{m} / \mathrm{z}$ values are similar to the formula weight of the respective complexes which further supports the proposed structure of the oxovanadium (IV) complexes.

On the basis of the elemental analysis, conductivity measurements, magnetic moment values, spectroscopic studies and literature review the structure of the complexes (Figure 2) could be illustrated as shown below:

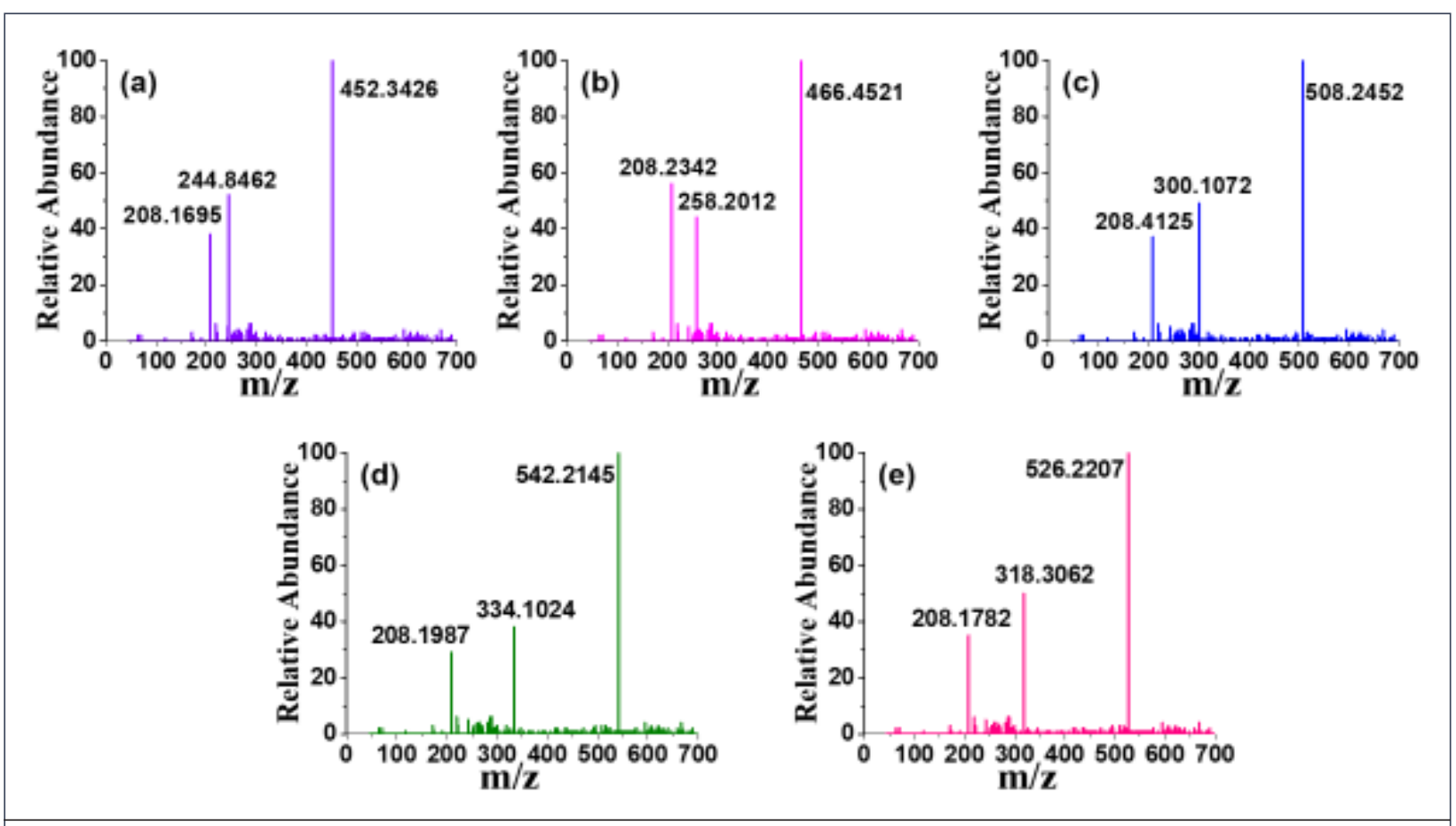

Figure 1: ESI-MS Spectrum of the Complexes; (a) [VO(sal-gly)(Dphen)], (b) [VO(sal-ala)(Dphen)], (c) [VO(salleu)(Dphen)], (d) [VO(sal-pheala)(Dphen)] and (e) [VO(sal-met)(Dphen)]

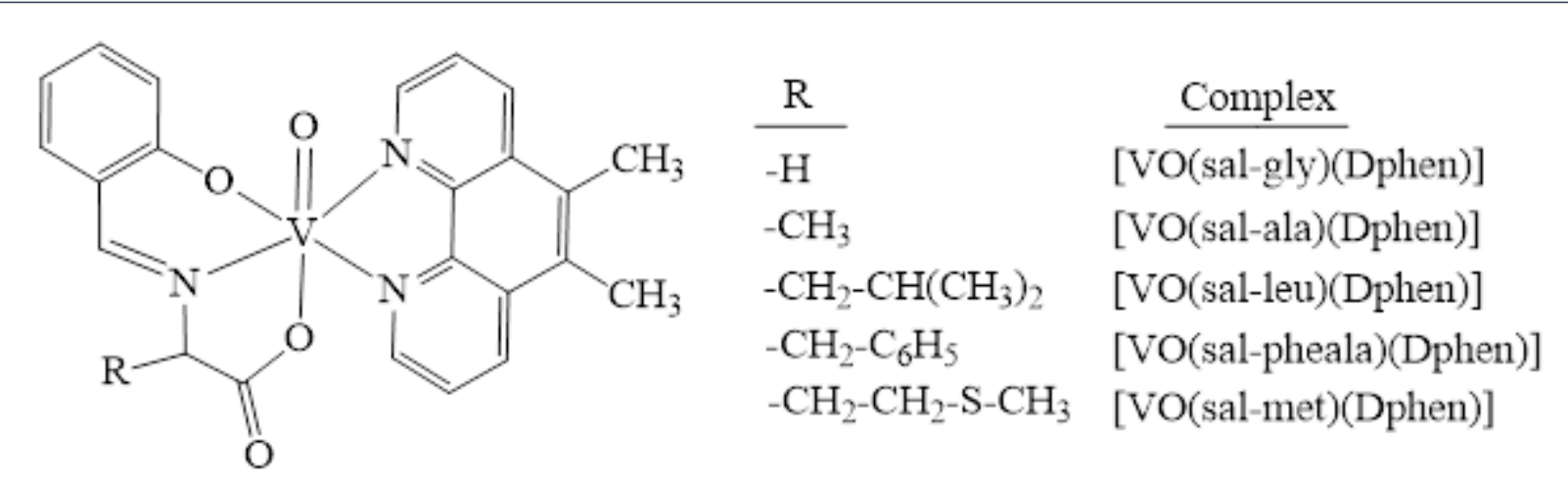

Figure 2: Proposed Structure of the Oxovanadium (IV) Complexes 


\section{Antibacterial Activity of the Complexes}

Antibacterial activities of the synthesized complexes are investigated by using the traditional disc diffusion method (Elachi et al., 2019; and Bitu et al., 2020). The complexes (50 mg/disc in DMSO solution) were screened for their antibacterial activity against two Gram positive bacteria Escherichia coli and Pseudomonas aeruginosa and two Gram negative bacteria Staphylococcus aureus and Bacillus cereus with Kanamycin (K-30) standard (Haque et al., 2005; Ali et al., 2020a; 2020b; and 2020c). The result shows that all the complexes have moderate to strong potential antibacterial activity against all the tested pathogens. The result is graphically represented in Figure 3.

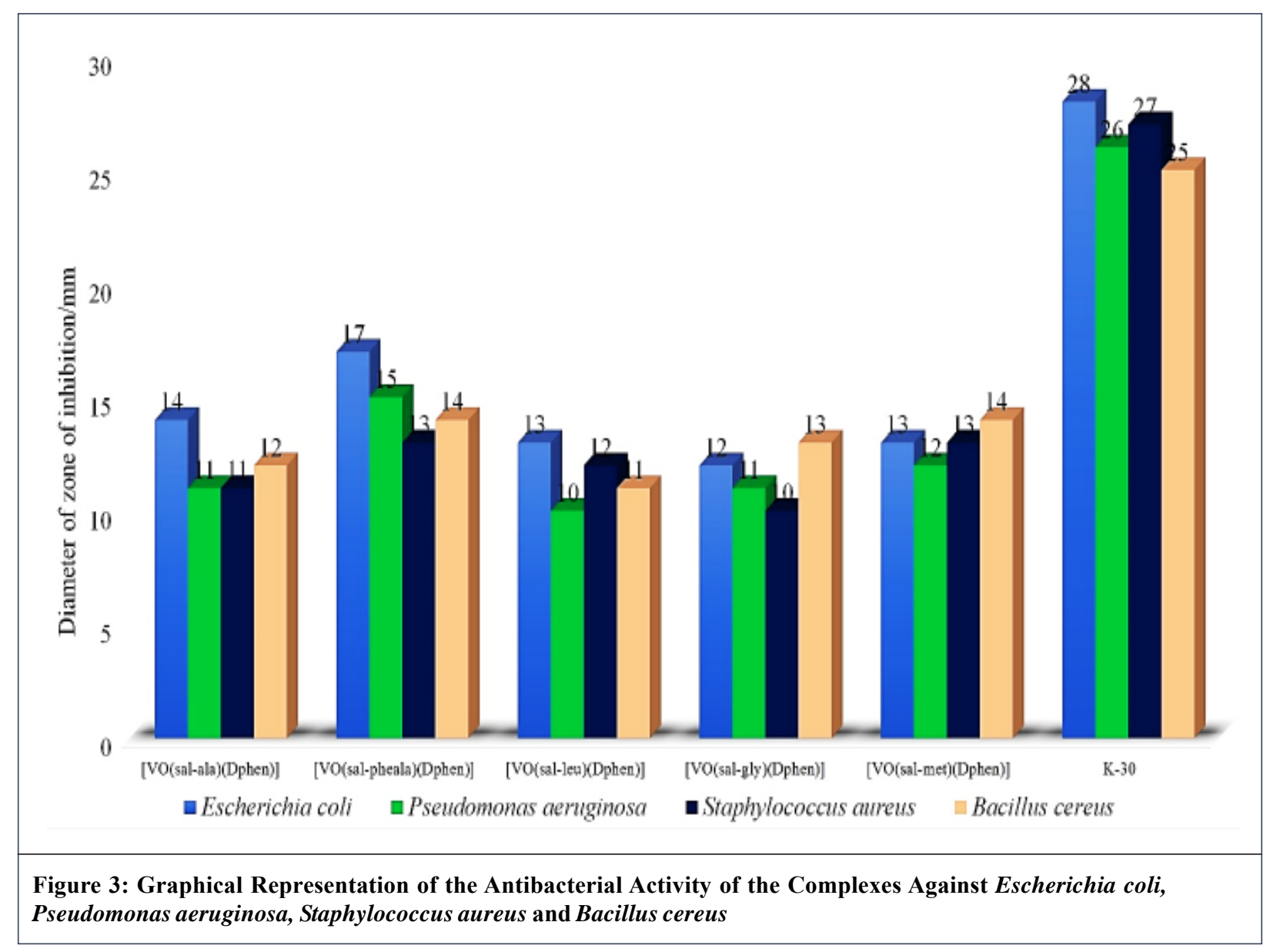

\section{Conclusion}

The $\mathrm{VO}^{2+}$ complexes of $\mathrm{O}, \mathrm{N}$, $\mathrm{O}$-donor amino acid Schiff bases and 5,6-Dimethyl-1,10-phenanthroline have been synthesized and characterized. The molar conductance values shows that the complexes are non-electrolytic in nature. The magnetic moment values reveal that the complexes contain paramagnetic behavior and are in accordance with the $\mathrm{d}^{1}$ electronic configuration of the $\mathrm{V}^{\mathrm{IV}} \mathrm{O}^{2+}$ moiety. IR spectral data indicates the coordination of tridentate amino acid Schiff base ligands to the vanadyl $\left(\mathrm{VO}^{2+}\right)$ ion. UV-Visible spectra appeared in the range $373-385 \mathrm{~nm}$ is due to LMCT transition. Thus, on the basis of physicochemical properties, elemental analysis, conductivity measurements, magnetic moment values, spectroscopic studies and literature review, the structure of the complexes (Figure 2) may be proposed as distorted octahedral geometry with $\mathrm{VO}_{3} \mathrm{~N}_{3}$ coordination environment. All the complexes were screened for their antibacterial activity against four human pathogenic bacteria; two Gram positive Escherichia coli and Pseudomonas aeruginosa and two Gram negative Staphylococcus aureus and Bacillus cereus with Kanamycin (K-30) standard. The result shows that all the complexes have moderate to strong potential antibacterial activity against all the tested organisms.

\section{Acknowledgment}

The authors are thankful to the Chairman, Department of Chemistry, University of Rajshahi, Rajshahi-6205, Bangladesh for the laboratory facilities. 


\section{References}

Al-Resayes, S.I., Shakir, M., Abbasi, A., and Amin, K.M.Y. (2012). Synthesis, Spectroscopic Characterization and Biological activities of $\mathrm{N}_{4} \mathrm{O}_{2}$ Schiff Base Ligand and its Metal Complexes of Co (II), Ni (II), Cu (II) and Zn (II). Lateef, A. Spectrochim. Acta, Part A, 93, 86.

Ali, M.M., Bitu, M.N.A., Hossain, M.S., Hossen, M.F., Asraf, M.A., Farooque, M.A., Hossain, M.M., and Kudrat-EZahan, M. (2020a). Comparative Studies on Synthesis, Characterization and Antibacterial Properties Between Schiff Base Co (II) Complex and Peroxo Complex. Asian J. of Chem. Sci., 8, 1.

Ali, M.M., Bitu, M.N.A., Hossain, M.S., Hossen, M.F., Asraf, M.A., Haque, M.M., Farooque, M.A., and Kudrat-EZahan, M. (2020b). Synthesis, Structural Characterizations and Biological Properties of Cd (II) and Zr (IV) Peroxo Complexes Containing Schiff Base Derived from Cinnamaldehyde and O-Aminobenzoic Acid. New Mat., Com. and App., 4, 173.

Ali, M.M., Bitu, M.N.A., Hossain, M.S., Hossen, M.F., Asraf, M.A., Farooque, M.A., and Kudrat-E-Zahan, M. (2020c). One Pot Synthesis of Cu (II) and Ni (II) Peroxo Complexes Containing Schiff Base: Physicochemical, Spectral and Antibacterial Investigations. Asian J. of Chem. Sci., 8, 15.

Arun, V., Sridevi, N., Robinson, P.P., Manju, S., and Yusuff, K.K.M. (2009). Ni (II) and Ru (II) Schiff Base Complexes as Catalysts for the Reduction of Benzene. J. Mol. Catal. A: Chem., 304, 191.

Bitu, M.N.A., Hossain, M.S., Zahid, A.A.S.M., Zakaria, C.M., and Kudrat-E-Zahan, M. (2019). Anti-Pathogenic Activity of $\mathrm{Cu}$ (II) Complexes Incorporating Schiff Bases: A Short Review. American J. of Het. Chem., 5, 11.

Bitu, N.A., Hossain, S., Islam, N., Kader, A., Islam, M.S., Haque, M.M., Hossen, F., Asraf, A., Mohapatra, R.K., and Kudrat-E-Zahan. (2020). Peroxo Complexes of Th (IV) and Zr (IV) Ions Containing Aspartic Acid and Amine Bases as Potential Biological Agents. Rus. J. of Gen. Chem., 90, 1553.

Cheng, L., Tang, J., Luo, H., Jin, X., Dai, F., Yang, J., Qian, Y., Li, X., and Zhou, B. (2010). Antioxidant and Antiproliferative Activities of Hydroxyl-Substituted Schiff Bases. Bioorg. Med. Chem. Lett., 20, 2417.

Dutta, S.K., Kumar, S.B., Bhattacharyya, S., Tiekink, E.R.T., and Chaudhury, M. (1997). Intramolecular Electron Transfer

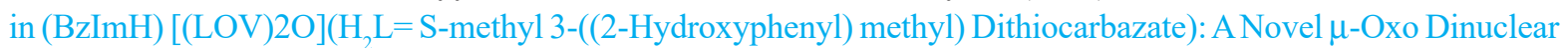
Oxovanadium (IV/V) Compound with a Trapped-Valence $\left(\mathrm{V}_{2} \mathrm{O}_{3}\right)^{3+}$ Core. Inorg. Chem., 36, 4954.

Dutta, S.L, and Lal R.A. (1988). Synthesis \& Characterization of Nitrato \& Acetato Complexes of Dioxouranium (VI) with Disalicylaldehyde Acyl Hydrazones. Indian. J. Chem., Sect. A, 27, 225.

Elachi, K.A., Hossain, M.S., Bitu, M.N.A., Zahid, A.A.S.M., Mohapatra, R.K., Mannan, M.A., Zakaria, C.M., and Kudrat-E-Zahan, M. (2019). Synthesis, Spectral and Thermal Characterization on Bioactive Complexes of Mg (II), Zn (II), Sn (II), VO (II) and Bi (III) Ions Containing Schiff Base Ligand. J. of Chem., Bio. and Phys. Sci., Sect. A: Chemical Sciences, 9, 201.

Haque, M.E., Rahman, M.Z., Pervin, M.M., Kabir, M.H., Imran, M.S., Ferdaus, K.M.K.B., and Khalekuzzaman, M. (2005). Biological Screening of Some Ferrocene Derivative Metal Complexes. Pak. J. of Bio. Sci., 8, 1746.

Kriza, A., and Mitu, L., and Stanica, N. (2005). Complex Combinations of Some "d" Transitional Metals with the Isonicotinoylhydrazone-2-Hydroxy-1-Naphthaldehyde Ligand. Rev. Chim. (Bucharest), 56, 137.

Kudrat-E-Zahan, Hossain, S., Haque, M.M., Banu, L.A., Matin, M.A., Bitu, N.A., Habib, A., Ashrafuzzaman, Uddin, N., and Islam, M.S. (2019). Antineoplastic, Bio-Chemical, Cytotoxic and Antimicrobial Investigation on Synthesized Schiff Base Co (II) Ion Complex. Biochem. \& Mol. Bio. 4, 35.

Macedo-Ribeiro, S., Hemrika, W., Revirie, R., Wever, R., and Messerschimdt, A. (1999). X-Ray Crystal Structures of Active Site Mutants of the Vanadium-Containing Chloroperoxidase from the Fungus Curvularia Inaequalis. J. Biol. Inorg. Chem., 4, 209.

Maurya, M. R., Khurana, S., Schulzke, C., and Rehder, D. (2001). Dioxo- and Oxovanadium (V) Complexes of Biomimetic Hydrazone ONO Donor Ligands: Synthesis, Characterisation, and Reactivity. Eur. J. Inorg. Chem., 779.

Noblía, P., Baran, E. J., Otero, L., Draper, P., Cerecetto, H., González, M., Piro, O.E., Castellano, E.E., Inohara, T., Adachi, Y., Sakurai, H., and Gambino, D. (2004). New Vanadium (V) Complexes with Salicylaldehyde Semicarbazone Derivatives: 
Synthesis, Characterization, and in Vitro Insulin-Mimetic Activity-Crystal Structure of [VvO2 (Salicylaldehyde Semicarbazone)]. Eur. J. Inorg. Chem., 322.

Pattanayak, P., Pratihar, J.L., Patra, D., Mitra, S., Bhattacharyya, A., Lee, H.M., and Chattopadhyay, S. (2009). Synthesis, Structure and Reactivity of Azosalophen Complexes of Vanadium (IV): Studies on Cytotoxic Properties. Dalton Trans., 6220 .

Pessoa, J.C., Calhorda, M.J., Cavaco, I., Correia, I., Duarte, M.T., and Fe-lix, V. (2002). Molecular Modelling Studies of Nsalicylideneamino Acidato Complexes of Oxovanadium (IV). Molecular and Crystal Structure of a New Dinuclear LOVIV_O-VV OL Mixed Valence Complex. J. Chem. Soc., Dalton Trans., 4407.

Pessoa, J.C., Calhorda, M.J., Cavaco, I., Costa, P.J., Correia, I., and Costa, D. (2004). N-Salicylideneamino Acidato Complexes of Oxovanadium (IV). The Cysteine and Penicillamine Complexes. J. Chem. Soc., Dalton Trans., 2855.

Ran, X., Wang, L., Cao, D., Lin, Y., and Hao, J. (2011). Synthesis, Characterization and in Vitro Biological Activity of Cobalt (II), Copper (II) and Zinc (II) Schiff base Complexes Derived from Salicylaldehyde and D, L-selenomethionine. Appl. Organomet. Chem., 25, 9.

Rao, P.V., Rao, R.N., and Ganorkar, M.C. (1988). Synthesis \& Structural Studies of Oxovanadium (IV), Manganese (II), Iron (II), Cobalt (II), Nickel (II) \& Copper (II) Complexes of N-(4-Methyl-8-acetoumbelliferonylidene)-N'-(isonicotinoyl) Hydrazine. Indian. J. Chem., Sect. A, 27, 73.

Sasmal, P.K., Patra, A.K., Nethaji, M., and Chakravarty, A.R. (2007). DNA Cleavage by New Oxovanadium (IV) Complexes of $\mathrm{N}$-salicylidene $\alpha$-amino Acids and Phenanthroline Bases in the Photodynamic Therapy Window. Inorg. Chem., 46,11112

Singh, S., Chakravorty, V., and Das, C.K. (1989). Mono-, Bi- \& Tri-Nuclear Dioxouranium (VI) Complexes with Oximes \& Polydentate Schiff Bases., Indian. J. Chem., Sect. A, 28, 256.

Tasiopoulos, A.J., Troganis, A.N., Evangelou, A., Raptopoulou, C.P., Terzis, A., Deligiannakis, Y., and Kabanos, T.A. (1999). Synthetic Analogues for Oxovanadium (IV)-Glutathione Interaction: An EPR, Synthetic and Structural Study of Oxovanadium (IV) Compounds with Sulfhydryl-Containing Pseudopeptides and Dipeptides. Chem. Eur. J., 5, 910 .

Thompson, K.H., McNeill, J.H., and Orvig, C. (1999). Vanadium Compounds as Insulin Mimics. Chem. Rev., $99,2561$.

Yue, H., Zhang, D., Shi, Z., and Feng, S. (2006). Synthesis and Characterization of Two Oxovanadium (IV) Schiff Base Complexes Derived from Amino Acids and Pyridoxal. Sol. State Sci., 8, 1368.

Cite this article as: Md. Nur Amin Bitu, Md. Saddam Hossain, Md. Ali Asraf, Md. Faruk Hossen and Md. Kudrat-EZahan (2021). Mixed Ligand Oxovanadium (IV) Complexes of 5,6-Dimethyl-1,10-phenanthroline and Amino Acid Schiff Bases Containing Salicylaldehyde: Synthesis and Characterization with Antibacterial Properties. African Journal of Pharmaceutical Sciences, 1(1), 47-53. doi: 10.51483/AFJPS.1.1.2021.47-53 